\title{
Glucagon-like peptide-1 (GLP-1) and the regulation of human invariant natural killer $T$ cells: lessons from obesity, diabetes and psoriasis
}

\author{
A. E. Hogan • A. M. Tobin • T. Ahern • M. A. Corrigan • G. Gaoatswe • R. Jackson • \\ V. O'Reilly • L. Lynch • D. G. Doherty • P. N. Moynagh • B. Kirby • J. O'Connell • \\ D. O'Shea
}

Received: 6 May 2011 /Accepted: 1 June 2011 / Published online: 9 July 2011

(C) The Author(s) 2011. This article is published with open access at Springerlink.com

\begin{abstract}
Aims/hypothesis The innate immune cells, invariant natural killer T cells (iNKT cells), are implicated in the pathogenesis of psoriasis, an inflammatory condition associated with obesity and other metabolic diseases, such as diabetes and dyslipidaemia. We observed an improvement in psoriasis
\end{abstract}

A. E. Hogan $\cdot$ T. Ahern $\cdot$ M. A. Corrigan $\cdot$ G. Gaoatswe $\cdot$

L. Lynch · J. O'Connell $\cdot$ D. O'Shea $(\bowtie)$

Department of Endocrinology, St Vincent's University Hospital,

University College Dublin,

Dublin 4, Ireland

e-mail: donal.oshea@hse.ie

\author{
A. E. Hogan - A. M. Tobin - T. Ahern - M. A. Corrigan • \\ G. Gaoatswe $\cdot$ L. Lynch $\cdot$ D. O'Shea \\ Obesity Immunology Group, ERC, Conway Institute, \\ St Vincent's University Hospital, UCD, \\ Dublin, Ireland
}

\author{
A. M. Tobin · B. Kirby \\ Department of Dermatology, \\ St Vincent's University Hospital, UCD, \\ Dublin, Ireland
}

R. Jackson • P. N. Moynagh

Molecular Immunology Group, Institute of Immunology,

National University of Ireland,

Maynooth, Ireland

V. O'Reilly • D. G. Doherty

Human Immunology Group, Institute of Molecular Medicine,

SJUH, Trinity College Dublin,

Dublin, Ireland

D. O'Shea

Department of Endocrinology, St Columcille's Hospital, Health Service Executive,

Loughlinstown, Ireland severity in a patient within days of starting treatment with an incretin-mimetic, glucagon-like peptide-1 (GLP-1) receptor agonist. This was independent of change in glycaemic control. We proposed that this unexpected clinical outcome resulted from a direct effect of GLP-1 on iNKT cells.

Methods We measured circulating and psoriatic plaque iNKT cell numbers in two patients with type 2 diabetes and psoriasis before and after commencing GLP-1 analogue therapy. In addition, we investigated the in vitro effects of GLP-1 on iNKT cells and looked for a functional GLP-1 receptor on these cells.

Results The Psoriasis Area and Severity Index improved in both patients following 6 weeks of GLP-1 analogue therapy. This was associated with an alteration in iNKT cell number, with an increased number in the circulation and a decreased number in psoriatic plaques. The GLP-1 receptor was expressed on iNKT cells, and GLP-1 induced a dose-dependent inhibition of iNKT cell cytokine secretion, but not cytolytic degranulation in vitro.

Conclusions/interpretation The clinical effect observed and the direct interaction between GLP-1 and the immune system raise the possibility of therapeutic applications for GLP-1 in inflammatory conditions such as psoriasis.

Keywords Anti-inflammatory · CREB · Diabetes · GLP-1 analogue - GLP-1 receptor Innate immune system .

Invariant NKT cells $\cdot$ Obesity $\cdot$ Psoriasis

Abbreviations
$\begin{array}{ll}\text { CREB } & \text { cAMP response element-binding protein } \\ \text { DPP-IV } & \text { Dipeptidyl peptidase-IV } \\ \alpha \text {-GalCer } & \alpha \text {-Galactosylceramide } \\ \text { GLP-1 } & \text { Glucagon-like peptide-1 }\end{array}$




$\begin{array}{ll}\text { GLP-1R } & \text { Glucagon-like peptide-1 receptor } \\ \text { iNKT cell } & \text { Invariant natural killer T cell } \\ \text { mAb } & \text { Monoclonal antibody } \\ \text { PASI } & \text { Psoriasis Area and Severity Index } \\ \text { PBMC } & \text { Peripheral blood mononuclear cell } \\ \text { PMA } & \text { Phorbol myristate acetate } \\ \text { RYGB } & \text { Roux-en-Y gastric bypass } \\ \text { TCR } & \text { T cell receptor }\end{array}$

\section{Introduction}

Psoriasis is an immune-mediated disease associated with obesity and other metabolic disorders, such as diabetes and dyslipidaemia [1-4]. Patients with psoriasis are more likely to be obese than non-psoriatic controls. Obesity is more prevalent in patients with severe rather than mild psoriasis [1]. Both conditions are associated with chronic systemic inflammatory activation $[5,6]$ and an increased risk of cardiovascular morbidity and mortality [7-9].

We have previously reported that obesity is associated with innate immune cell dysfunction, a key feature of psoriasis $[10,11]$. We have demonstrated that, compared with lean individuals, obese individuals have decreased circulating natural killer cell number and function [10], and also have lower invariant natural killer $\mathrm{T}$ cell (iNKT cell) accumulation in the omentum [11]. iNKT cells are a rare subset of innate $\mathrm{T}$ cells that exert multiple immunoregulatory functions. They recognise glycolipid antigens, such as the marine sponge-derived glycolipid $\alpha$-galactosylceramide $(\alpha$-GalCer), presented on the MHC-like molecule, CD1d. Upon stimulation, iNKT cells can rapidly produce multiple cytokines that direct the immune response towards a proinflammatory (Th1 or Th17) or an anti-inflammatory (Th2) bias [12]. iNKT cells are implicated in the pathogenesis of various obesity-related diseases, including psoriasis [13], cancer $[14,15]$ and arthritis $[16,17]$.

The incretin pathway is a therapeutic target for obesity and diabetes [18]. The incretin effect results from release of hormones such as glucagon-like peptide-1 (GLP-1) from intestinal cells in response to glucose ingestion, enhancing insulin release and reducing postprandial excursions of plasma glucose. Long-acting GLP-1 analogues, GLP-1 receptor agonists and inhibitors of GLP-1 enzymatic degradation are increasingly used in type 2 diabetes to improve glycaemic control and enhance weight loss. The GLP-1 receptor (GLP-1R) is widely distributed in pancreatic islets, brain, heart, kidney and the gastrointestinal tract [19]. GLP-1R has also been demonstrated in murine immune tissues [20], and on $\mathrm{T}$ and $\mathrm{B}$ lymphocytes from mice $[20,21]$ and humans [22]. Several reports indicate a role for the incretin hormones in regulation and migration of murine [20, 21, 23] and human [22] T lymphocytes. The effects of incretin hormones on human iNKT cell function have not yet been described.

In the present study, we observed an unexpected beneficial effect on co-existing psoriasis in an obese, type 2 diabetes patient on GLP-1 therapy. The improvement in psoriasis symptoms began within days, and prior to weight loss or significant improvements in glycaemic control. We hypothesised that GLP-1 may influence psoriasis severity by interacting directly with the innate immune system, in particular iNKT cells.

\section{Methods}

Index patient The index patient was a 60 -year-old woman with type 2 diabetes and BMI $37 \mathrm{~kg} / \mathrm{m}^{2}$. She had had extensive, refractory psoriasis since childhood, requiring several inpatient admissions and multiple treatments with systemic agents. Prior to treatment she had a Psoriasis Area and Severity Index (PASI) greater than 15. She complained of extensive, itchy psoriasis causing marked sleep disruption. A GLP-1R agonist, exenatide, was initiated for treatment of type 2 diabetes. Within 2 days she reported an improvement in psoriasis severity, with decreased itch and less sleep disruption. By 2 weeks the PASI was 10.5 . This patient experienced nausea in association with exenatide, requiring discontinuation after 2 months of treatment. The psoriasis symptoms quickly began to recur, with PASI reaching 15.3 by the end of 2 weeks. The patient then commenced a trial of liraglutide, a GLP-1 analogue, and reported prompt improvement in itch and thinning of psoriatic plaques. By the end of 3 weeks the PASI had fallen to 10.2. After 9 months of liraglutide therapy psoriasis symptoms remain stable (PASI 10.5).

Other participants Following the observed improvement in psoriasis in the index patient, we started two additional obese participants with psoriasis and well-controlled type 2 diabetes on liraglutide. St Vincent's University Hospital Medical Research Ethics Committee approved this study, and written informed consent was obtained from each participant prior to the start of any research activities. We characterised the circulatory and plaque levels of iNKT cells at baseline and following 6 weeks of GLP-1 analogue therapy in these two participants. The clinical improvement in the index patient was unexpected so we were unable to study the immunological profile before and after treatment in this case.

Enumeration of iNKT cells by flow cytometry Peripheral blood mononuclear cells (PBMCs) were isolated from patients by density gradient centrifugation $(300 \mathrm{~g})$ over Lymphoprep (Nycomed, Oslo, Norway). Skin biopsies were 
obtained from psoriasis plaques and digested with $0.5 \%$ (wt/vol.) collagenase type 1A (Sigma-Aldrich, Wicklow, Ireland) to obtain single-cell suspensions. iNKT cells were enumerated by staining with a pairing of phycoerythrinconjugated anti-iNKT cell monoclonal antibody (mAb) (clone 6B11) and phycoerythrin-Cy5-conjugated anti-CD3 $\mathrm{mAb}$, or with FITC-conjugated anti-V $\alpha 24 \mathrm{~T}$ cell receptor (TCR) $\mathrm{mAb}$ and a phycoerythrin-conjugated anti-V $\beta 11$ $\mathrm{mAb}$. Cells were acquired using a flow cytometer (FACS Caliber, BD Biosciences, NJ, USA) and analysed using Cell Quest Pro (BD Biosciences) using Flow Minus One controls. iNKT cell numbers are expressed as a percentage of lymphocytes or T cells.

Generation of iNKT cell lines PBMCs were isolated from healthy blood donors as previously described. iNKT cells were isolated from PBMCs by magnetic bead separation with an anti-iNKT cell bead (Miltenyi Biotec, BergischGladbach, Germany). iNKT cells were further enriched by flow cytometric sorting of 6B11-positive cells using a cell sorter (FACS Aria; BD Biosciences). Sorted iNKT cells were expanded in vitro by culturing 1,000 iNKT cells in complete RPMI medium and stimulating them with $1 \mu \mathrm{g} / \mathrm{ml}$ phytohaemagglutinin (Sigma-Aldrich) and $250 \mathrm{U} / \mathrm{ml} \mathrm{IL-2}$ (R\&D Systems, Oxford, UK) in the presence of an excess $\left(2 \times 10^{5}\right)$ of irradiated allogeneic PBMCs prepared from two donors. After 24 and $48 \mathrm{~h}$, cell culture medium was replaced with medium containing $250 \mathrm{U} / \mathrm{ml} \mathrm{IL}-2$. Cell lines were expanded for 2 to 4 weeks in the presence of IL-2 medium. Purity and phenotype of iNKT cell lines were assessed by flow cytometry after staining the cells with mAbs specific for $\mathrm{CD} 3,6 \mathrm{~B} 11, \mathrm{~V} \alpha 24, \mathrm{~V} \beta 11, \mathrm{CD} 4$ and CD8.

Glycolipid preparation $\alpha$-GalCer (Funakoshi, Tokyo, Japan) stocks were prepared by suspending solid $\alpha$-GalCer in DMSO to a final concentration of $1 \mathrm{mg} / \mathrm{ml}$ by heating for $2 \mathrm{~min}$ at $80^{\circ} \mathrm{C}$, followed by sonication for $5 \mathrm{~min}$ and vortexing for $1 \mathrm{~min}$. These stocks were stored at $-20^{\circ} \mathrm{C}$.

Analysis of cytokine secretion by iNKT cells iNKT cells were stimulated in vitro using CD1d-transfected C1R cells pulsed with glycolipid. For the cytokine production assay, $2 \times$ $10^{5} \mathrm{C} 1 \mathrm{R}$-transfected cells were cultured in round-bottomed 96-well tissue culture plates and pulsed with $100 \mathrm{ng} / \mathrm{ml}$ glycolipid antigen for $1 \mathrm{~h}$ before adding an equal number of iNKT cells, with or without GLP-1 $(1-150 \mu \mathrm{g})$ or the GLP-1 analogue liraglutide $(15 \mu \mathrm{g} / \mathrm{ml})$. Phorbol myristate acetate (PMA) $(10 \mathrm{ng} / \mathrm{ml})$ and ionomycin $(1 \mu \mathrm{g} / \mathrm{ml})$ were used as a positive control, and iNKT cells in the absence of C1R cells and $\alpha \mathrm{GalCer}$ as a negative control. Pre-treatment with $10 \mu \mathrm{g} / \mathrm{ml}$ exendin 9-39 was used in blocking experiments prior to stimulation and GLP-1 treatment. After $24 \mathrm{~h}$, supernatant fraction concentrations of IFN- $\gamma$ and IL-4 were determined by ELISA.

Analysis of cytolytic degranulation of iNKT cells iNKT cells, treated with or without the GLP-1 analogue $(15 \mu \mathrm{g} / \mathrm{ml})$, were co-cultured with $\mathrm{CD}_{1} \mathrm{~d}^{+} \mathrm{HeLa}$ cells and Jurkat target cells. Cells were examined by flow cytometric analysis for CD107a expression on 6B11-positive effector iNKT cells. In these experiments, iNKT cells and target cells were cocultured for $4 \mathrm{~h}$ in the presence of anti-CD107a mAb and monensin $(25 \mu \mathrm{mol} / \mathrm{l}$; Sigma-Aldrich). Monensin was used to prevent re-internalisation of $\mathrm{CD} 107 \mathrm{a}$.

Detection and quantification of GLPIR mRNA RNA was extracted from previously described iNKT cell lines using a total RNA isolation kit as per the manufacturer's instructions (Macherey-Nagel; Thermo Fisher Scientific, Loughborough, UK). A cell concentration of $1.5 \times 10^{6}$ was used. The RNA was quantified using the nano-drop system and qualitatively assessed using a bioanalyser (Agilent Biosystems, Cork, Ireland). The integrity of the RNA was determined by the RNA integrity number (RIN). A starting concentration of $1 \mu \mathrm{g}$ RNA was used for cDNA synthesis using a cDNA synthesis kit (Omniscript; Qiagen, Crawley, UK) including a negative control. The $50 \mu \mathrm{l}$ PCR reaction mix was made up using a kit (GoTaq Flexi kit; Promega, Madison, WI, USA), with $10 \mu \mathrm{l}$ reaction buffer, $1 \mathrm{mmol} / 1 \mathrm{MgCl}_{2}, 0.2 \mathrm{~mm}$ dNTPs, $0.2 \mu \mathrm{mol} / 1$ forward and reverse primers, and $1.25 \mathrm{U}$ Taq polymerase using a 1:10 dilution of stock cDNA as the PCR template. GLPIR expression analysis was quantified using the reference gene $\beta$-actin. The optimal PCR conditions for GLP1R and $\beta$-actin were: $95^{\circ} \mathrm{C}$ for $3 \mathrm{~min} ; 35$ cycles at $95^{\circ} \mathrm{C}$ for $30 \mathrm{~s}$, $57^{\circ} \mathrm{C}$ for $30 \mathrm{~s}$ and $72^{\circ} \mathrm{C}$ for $30 \mathrm{~s}$; and then $72^{\circ} \mathrm{C}$ for $7 \mathrm{~min}$. No template and negative controls containing water-based cDNA were used to rule out component contamination. Results were visualised by means of $1 \%$ agarose gels and using the AutoChemi System (UVP BioImaging Systems, Cambridge, UK). Real-time PCR was performed using Qiagen QuantiTect primers for GLPIR and $\beta$-actin in cultured iNKT cell lines and in HEK 293, which are negative for GLP1R. The master mix was comprised of 12.5 $\mu$ l SYBR Green (Promega), $1 \mu 1$ of a 1:10 dilution of stock cDNA as the PCR template and $2.5 \mu \mathrm{l}$ of primer assay. No template controls were used to eliminate reagent contamination. The RT-PCR conditions were $95^{\circ} \mathrm{C}$ for $10 \mathrm{~min}$ and 40 cycles of $94^{\circ} \mathrm{C}$ for $15 \mathrm{~s}, 55^{\circ} \mathrm{C}$ for $30 \mathrm{~s}$ and $72^{\circ} \mathrm{C}$ for $30 \mathrm{~s}$.

Primers for GLP1R were: forward 5-TCAAGGTCA ACGGCTTATTAG-3, reverse 5-TAACGTGTCCCTAGAT GAACC-3. Primers for $\beta$-actin were: forward 5-CACCTT CACCGTTCCAGTT-3, reverse 5-CTCTTCCAGCCAGCC TTCCTTCCT-3. 
Investigation of GLP-1R abundance by intracellular flow cytometry iNKT cells $\left(2 \times 10^{5}\right)$ were surface-stained with the iNKT cell TCR mAb anti-6B11 (FITC), anti-CD4 and anti-CD3 (APC). Cells were fixed using 4\% paraformaldehyde [wt/vol.], permeabilised using $0.2 \%$ saponin and then incubated with the anti-GLP-1R mAb (phycoerythrin) or relevant isotype control. Cells then underwent flow cytometry and results were analysed using FlowJo software (Treestar, Ashland, OR, USA).

cAMP assay iNKT cells $\left(1.5 \times 10^{6}\right)$ were seeded in the presence or absence of plate-bound anti-CD3 $(2 \mu \mathrm{g} / \mathrm{ml})$ and cultured with the GLP-1 analogue $(15 \mu \mathrm{g} / \mathrm{ml})$ for the indicated times. As a positive control, cells were incubated for $15 \mathrm{~min}$ with the cAMP phosphodiesterase inhibitor, 3-isobutyl-1methylxanthine $(500 \mu \mathrm{mol} / \mathrm{l})$, and then stimulated for another $30 \mathrm{~min}$ with forskolin $(30 \mu \mathrm{mol} / \mathrm{l})$. Cells were washed twice with ice-cold PBS $(1 \mathrm{ml})$, lysed in lysis buffer $(250 \mu \mathrm{l})$ and subjected to two freeze-thaw cycles. Lysates were assessed for levels of intracellular cAMP using a cAMP assessment kit as per the manufacturer's instructions (R\&D Systems).

Measurement of cAMP response element-binding protein phosphorylation iNKT cells $\left(2 \times 10^{6}\right)$ were seeded in the presence or absence of plate-bound anti-CD3 $(2 \mu \mathrm{g} / \mathrm{ml})$ and cultured with the GLP-1 analogue $(15 \mu \mathrm{g} / \mathrm{ml})$ or lipopolysaccharide $(100 \mathrm{ng} / \mathrm{ml})$ for the indicated times. Cells were washed in ice-cold PBS (1 ml) and lysed in RIPA lysis buffer $(50 \mu \mathrm{l})(50 \mathrm{mmol} / \mathrm{l}$ Tris-HCl, $\mathrm{pH} 7.5$, containing $150 \mathrm{mmol} / \mathrm{l} \mathrm{NaCl}, 1 \%$ [wt/vol.] IGEPAL, $1 \%$ [wt/vol.] sodium deoxycholate, $1 \mathrm{mmol} / 1 \mathrm{Na}_{3} \mathrm{VO}_{4}, 1 \mathrm{mmol} / 1$ dithiothreitol, $1 \mathrm{mmol} / \mathrm{l}$ phenylmethylsulfonyl fluoride and protease inhibitor mixture consisting of leupeptin $[25 \mu \mathrm{g} /$ $\mathrm{ml}]$, aprotinin $[25 \mu \mathrm{g} / \mathrm{ml}]$, benzamidine $[1 \mathrm{mmol} / \mathrm{l}]$ and trypsin inhibitor $[10 \mu \mathrm{g} / \mathrm{ml}])$. Cell lysates were centrifuged at $12,000 \mathrm{~g}$ for $10 \mathrm{~min}$. The supernatant fractions were mixed with $4 \times$ sample loading buffer $(0.125 \mathrm{~mol} / 1$ Tris$\mathrm{HCl}$, pH 6.8 , containing $20 \%$ [wt/vol.] glycerol, $4 \%$ [wt/ vol.] SDS, $1.4 \mathrm{~mol} / 1$ 2-mercaptoethanol and $0.0025 \%$ [wt/ vol.] Bromophenol Blue). Samples were then resolved by SDS-PAGE, transferred to nitrocellulose membrane and probed for immunoreactivity using anti-phospho-cAMP response element-binding protein (CREB) (Santa Cruz, Heidelberg, Germany), anti-CREB (Santa Cruz) and anti$\beta$-actin (Sigma-Aldrich) specific antibodies. Immunoreactive bands were detected using an infrared imaging system (Odyssey; LI-COR Biosciences, Lincoln, NE, USA) according to the manufacturer's instructions.

Statistical analysis All statistical analyses were performed with Prism version 5.0b software (GraphPad Software, San Diego, CA, USA). Data are presented as mean \pm SEM. Groups were compared using Student's $t$ test or Mann-
Whitney $U$ test as appropriate. $p$ values of $p<0.05$ were considered statistically significant.

\section{Results}

GLP-1 analogue therapy improves psoriasis and is associated with a redistribution of $i N K T$ cells between the circulation and psoriatic plaques Psoriasis improved in both participants

Table 1 Clinical profile and iNKT cell data from non-index participants 1 and 2 at baseline and 6 weeks following commencement of GLP-1 analogue treatment

\begin{tabular}{|c|c|c|}
\hline Variable & Participant 1 & Participant 2 \\
\hline Age (years) & 48 & 49 \\
\hline Sex & Male & Male \\
\hline Diabetes duration (years) & 2 & 4 \\
\hline \multicolumn{3}{|l|}{ Co-morbidities } \\
\hline Hypertension & Yes & Yes \\
\hline Dyslipidaemia & No & Yes \\
\hline Osteoarthritis & Yes & No \\
\hline \multicolumn{3}{|l|}{ Relevant medications } \\
\hline Metformin & Yes & Yes \\
\hline Aspirin & Yes & Yes \\
\hline Diuretic & Yes & No \\
\hline Calcium channel blocker & Yes & Yes \\
\hline ACE inhibitor & No & Yes \\
\hline Statin & No & Yes \\
\hline Psoriasis treatment $\mathrm{t}^{\mathrm{a}}$ & No & No \\
\hline \multicolumn{3}{|l|}{ Body weight (kg) } \\
\hline Baseline & 159.1 & 137.8 \\
\hline 6 weeks & 154.0 & 131.6 \\
\hline \multicolumn{3}{|l|}{ BMI $\left(\mathrm{kg} / \mathrm{m}^{2}\right)$} \\
\hline Baseline & 48.0 & 43.0 \\
\hline 6 weeks & 46.5 & 41.1 \\
\hline \multicolumn{3}{|l|}{$\mathrm{HbA}_{1 \mathrm{c}}, \%(\mathrm{mmol} / \mathrm{mol})$} \\
\hline Baseline & $5.7(38)$ & $5.9(40)$ \\
\hline 6 weeks & $5.6(37)$ & $5.8(39)$ \\
\hline \multicolumn{3}{|l|}{ PASI } \\
\hline Baseline & 13.2 & 4.8 \\
\hline 6 weeks & 10.8 & 3.8 \\
\hline \multicolumn{3}{|c|}{ iNKT cells ( $\%$ of lymphocytes) } \\
\hline \multicolumn{3}{|l|}{ Skin } \\
\hline Baseline & 2.16 & 0.32 \\
\hline 6 weeks & 0.07 & 0.00 \\
\hline \multicolumn{3}{|l|}{ Blood } \\
\hline Baseline & 0.15 & 0.16 \\
\hline 6 weeks & 0.6 & 0.57 \\
\hline
\end{tabular}

${ }^{\text {a }}$ Topical or oral treatment within previous 6 months 
following 6 weeks' treatment with liraglutide. The PASI improved from 13.2 to 10.8 in participant 1 and from 4.8 to 3.8 in participant 2 . iNKT cell number increased in the circulation following 6 weeks of therapy. This was accompanied by a decrease in iNKT cell number in psoriatic plaques (Table 1).

iNKT cells express GLPIR and signal in response to GLP-1 Given the capacity of the GLP-1 agonist to promote such clear re-distribution of iNKT cells from the skin into the circulation, we next assessed the ability of GLP-1 to act directly on iNKT cells. This was addressed by initially probing for GLP1R expression in these cells and investigating the ability of GLP-1 to trigger downstream intracellular signalling pathways. We examined polyclonal iNKT cell lines for human GLP1R by conventional PCR and realtime PCR. All lines were found to express GLP1R mRNA (Fig. 1a, b). To further complement this finding, intracellular flow cytometry was employed to confirm that GLP-1R is also produced at the protein level in iNKT cells (Fig. 1c). We next assessed the ability of GLP-1R-producing iNKT cells to signal in response to GLP-1. Given that GLP-1R is a G-protein-coupled receptor that couples to the stimulatory Gs protein and activates adenylate cyclase and hence cAMP production, we examined the ability of GLP-1 to regulate levels of cAMP in iNKT cells. Stimulation of GLP-1R by the GLP-1 analogue resulted in a time-dependent upregulation of levels of cAMP (Fig. 2a). While levels of cAMP were somewhat reduced in CD3-activated iNKT cells, stimulation of GLP-1R in these latter cells also showed time-dependent increases in levels of cAMP. Given that cAMP can activate the downstream enzyme protein kinase A, which in turn phosphorylates the transcription factor CREB, we were keen to show that the GLP-1R could also trigger these downstream signalling components. Stimulation of GLP-1R induced a time-dependent phosphorlyation of the transcription factor CREB and was further augmented when iNKT cells were activated with CD3 (Fig. 2b). There was no change in total levels of CREB or the housekeeping protein $\beta$-actin. These findings confirm that iNKT cells produce a functional GLP-1R, which can respond to GLP-1 and trigger downstream signal transduction cascades.

GLP-1 modulates iNKT cell cytokine production in a GLP$1 R$-dependent manner We next investigated the effects of GLP-1 on the function of iNKT cells. Native GLP-1 increased cytokine production by approximately two fold in resting iNKT cells (IFN- $\gamma p<0.0001$, IL-4 $p<0.005$; Fig. $3 \mathrm{a}, \mathrm{b})$. This occurred independently of $\alpha \mathrm{GalCer}$.
Fig. 1 iNKT cells express GLP-1R. a Expression of GLPIR mRNA by iNKT cell lines as determined by RT-PCR. Values were normalised to levels of $\beta$-actin $(n=4)$. b Quantification of expression of GLPIR by iNKT cells measured by realtime PCR; expression was also measured on a GLP-1R-negative HEK-293 cell line as a negative control; $n=3 ;{ }^{\dagger} p<0.0001$. c

Flow cytometry dot plots showing representative HEK-293 cell line, $\mathrm{CD}^{+} \mathrm{T}$ cell line and iNKT cell line stained with the $\mathrm{mAb}$ GLP-1R phycoerythrin (PE) and mAbs for either CD3 APC (T cells) or iNKT cell TCR FITC (iNKT cells). FMO, Flow Minus One control for each cell line. Gates were determined by FMO and unstained samples (not shown) $(n=5)$

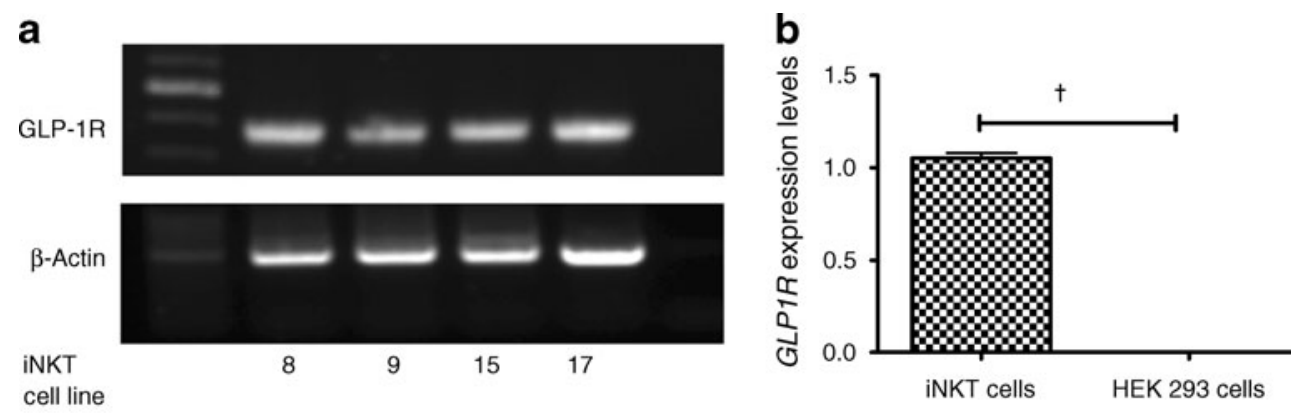

C

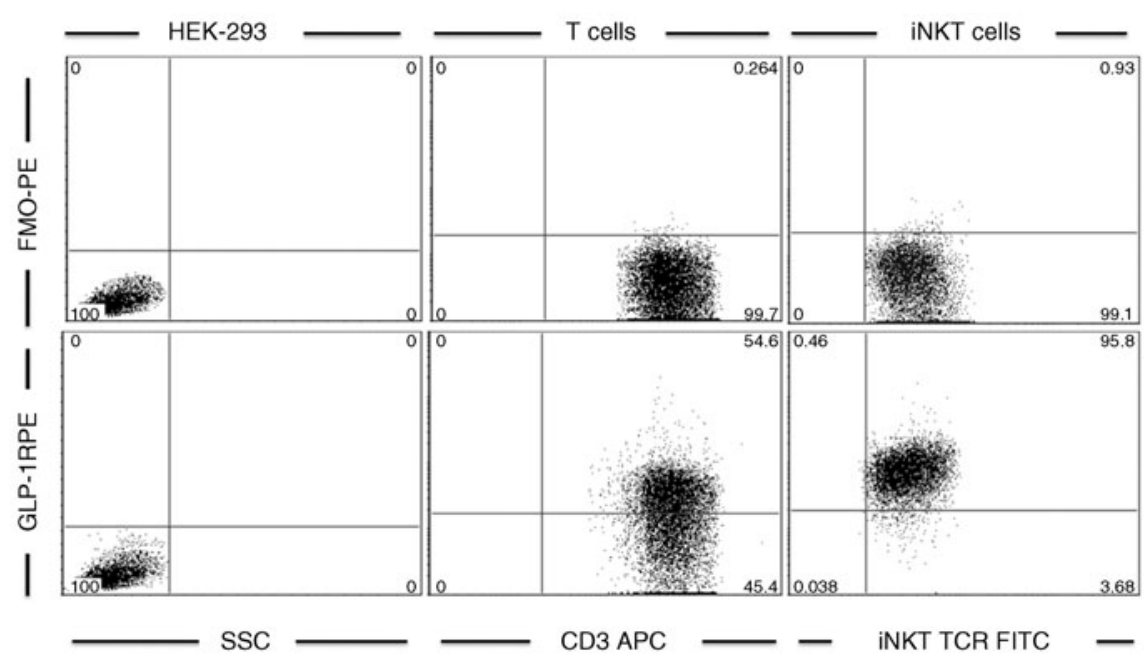


a

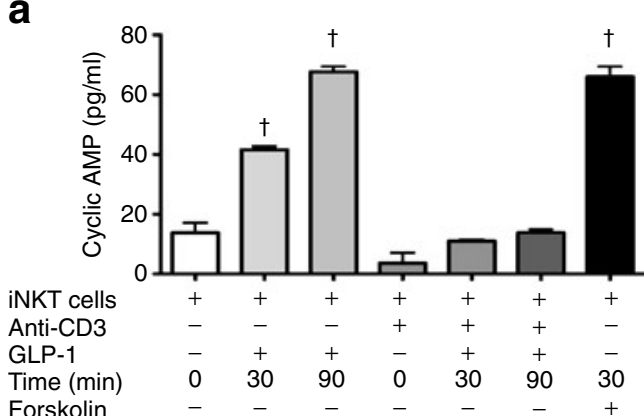

b

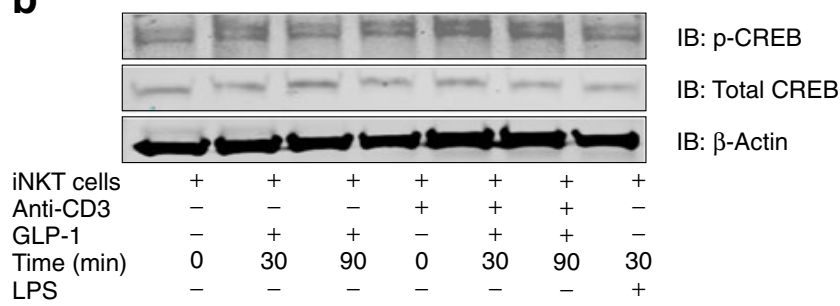

Fig. 2 Activation of GLP-1R on iNKT cells results in upregulation of cAMP and CREB phosphorylation. a Quantification of cAMP. iNKT cells $\left(1.5 \times 10^{6}\right)$ were seeded in the presence or absence of plate-bound anti-CD3 $(2 \mu \mathrm{g} / \mathrm{ml})$ and cultured with the GLP-1 analogue $(15 \mu \mathrm{g} / \mathrm{ml})$ for the indicated times. As a positive control, cells were incubated for 15 min with the cAMP phosphodiesterase inhibitor, 3-isobutyl-1methylxanthine $(500 \mathrm{~mol} / \mathrm{l})$, and then stimulated for another $30 \mathrm{~min}$ with forskolin $(30 \mu \mathrm{mol} / \mathrm{l}) \mathrm{cAMP}$. Cell extracts were prepared and assayed for levels of cAMP. ${ }^{\dagger} p<0.0001$. b iNKT cells $\left(2 \times 10^{6}\right)$ were seeded in the presence or absence of plate-bound anti-CD3 $(2 \mu \mathrm{g} / \mathrm{ml})$ and cultured with the GLP-1 analogue $(15 \mu \mathrm{g} / \mathrm{ml})$ or lipopolysaccharide (LPS, $100 \mathrm{ng} / \mathrm{ml}$ ) for the indicated times. Cell lysates were subjected to SDS-PAGE and analysed by western blotting using antiphospho-CREB, anti-CREB and anti- $\beta$-actin antibodies

However, GLP-1 showed dose-dependent inhibitory effects on the ability of $\alpha \mathrm{GalCer}$-loaded CD1d-transfected C1R cells to induce IFN- $\gamma$ and IL-4 production in iNKT cells (Fig. 3c, d). As the GLP-1R antagonist exendin 9-39 abrogated the capacity of GLP-1 to modulate iNKT cell cytokine production, the above inhibitory effects of GLP-1 on stimulated iNKT cells must be mediated via GLP-1R (Fig. 4a, b). To determine whether GLP-1 modulation was due to interference in the interaction between CD1d/ $\alpha$ GalCer and the $T$ cell receptor complex, we stimulated iNKT cells with PMA/ionomycin in the absence and presence of GLP-1. We observed a significant reduction in cytokine (IFN- $\gamma$ and IL-4) upon the addition of GLP-1 to stimulated iNKT cell cultures (Fig. 4c, d), indicating that GLP-1 does not directly target the CD1d/TCR complex interaction.

The GLP-1 analogue liraglutide modulates iNKT cell cytokine production, but not cytolytic degranulation GLP1 has a very short half-life in vivo and thus longer-acting analogues, such as liraglutide, are used in the clinical a

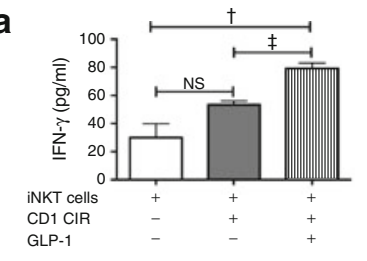

C

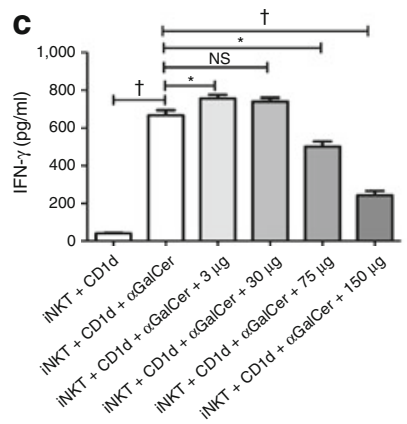

b
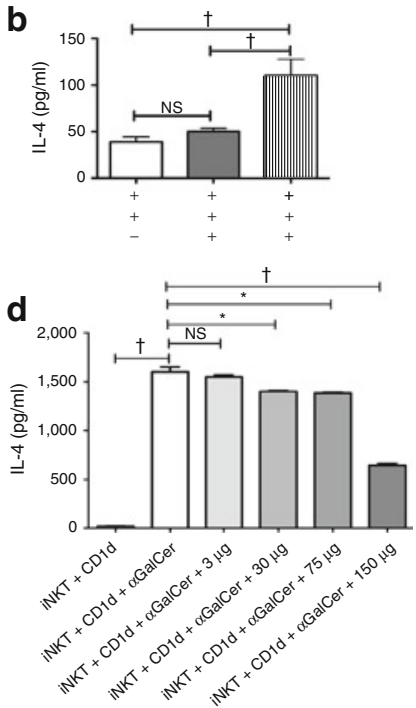

Fig. 3 GLP-1 modulates iNKT cell cytokines. IFN- $\gamma$ (a) and IL-4 (b) production by iNKT cells $\left(1 \times 10^{5}\right)$ after $24 \mathrm{~h}$ co-culture at a 1:1 ratio with CD1d-transfected C1R cells unloaded in the absence or presence of GLP-1 $(150 \mu \mathrm{g} / \mathrm{ml})(n=5)$. IFN- $\gamma(\mathbf{c})$ and IL-4 (d) production by iNKT cells after $24 \mathrm{~h}$ co-culture with CD1d-transfected C1R cells loaded or unloaded with $100 \mathrm{ng} / \mathrm{ml}$ of $\alpha \mathrm{GalCer}$ in presence of increasing concentrations of GLP-1 $(0-150 \mu \mathrm{g} / \mathrm{ml}, n=3)$. Cytokine concentrations were measured by ELISA and analysed using GraphPad Prism $(n=3) .{ }^{*} p<0.05,{ }^{\dagger} p<0.005,{ }^{\star} p<0.0001$

setting. We investigated whether liraglutide could mimic the regulatory effects of endogenous GLP-1 on iNKT cells. As seen with native GLP-1, the GLP-1 analogue significantly decreased production of IFN- $\gamma$ and IL-4 $(p<0.0001$; Fig. 5a). Finally, we investigated whether the GLP-1 analogue modulated the cytolytic degranulation of stimulated iNKT cells, but observed no effect on mobilisation of CD $107^{+}$cytolytic granules (Fig. 5 c).

\section{Discussion}

We have observed an improvement in psoriasis following GLP-1 therapy in our index patient and two other participants with obesity and type 2 diabetes. We have demonstrated the presence of iNKT cells in psoriasis lesions, associated with a relative depletion in circulating iNKT cell number, and a reversal of this ratio following 6 weeks of therapy with a GLP-1 analogue in the two non-index participants. GLP-1R was expressed on iNKT cells and modulated cytokine production in vitro following stimulation with native GLP-1 or the GLP-1 analogue, liraglutide. The GLP-1 analogue did not inhibit iNKT cell cytotoxicity function.

iNKT cells have been described as the 'Swiss-Army knife' of the immune system [24]. They represent less than $1 \%$ of all peripheral blood $\mathrm{T}$ cells, but even so are potent 

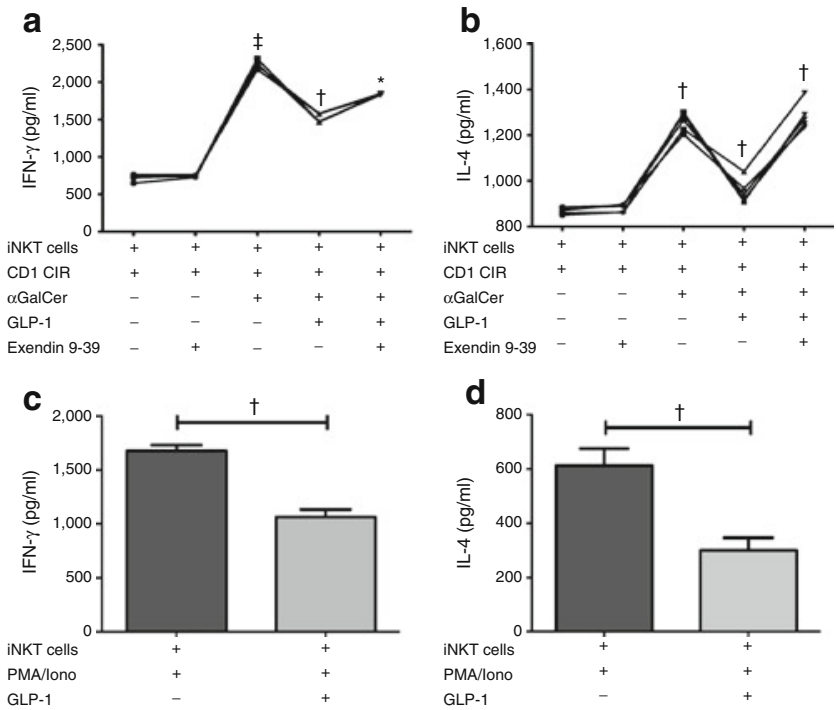

Fig. 4 GLP-1 modulation of iNKT cell cytokine production is GLP-1Rdependent. IFN- $\gamma\left(\right.$ a) and IL-4 (b) production by iNKT cells $\left(1 \times 10^{5}\right)$ that were incubated for $1 \mathrm{~h}$ with or without $10 \mu \mathrm{g} / \mathrm{ml}$ exendin 9-39. Cells were then co-cultured at a 1:1 ratio with $\mathrm{CD} 1 \mathrm{~d}$-transfected $\mathrm{C} 1 \mathrm{R}$ cells unloaded or loaded with $100 \mathrm{ng} / \mathrm{ml} \alpha \mathrm{GalCer}$ in the presence of $150 \mu \mathrm{g} / \mathrm{ml}$ native GLP-1 for $24 \mathrm{~h}(n=3)$. IFN- $\gamma$ (c) and IL-4 (d) production by iNKT cells $\left(1 \times 10^{5}\right)$ stimulated with PMA and ionomycin (Iono) in the absence or presence of $150 \mu \mathrm{g} / \mathrm{ml}$ native GLP-1 for $24 \mathrm{~h}$ $(n=3)$. Cytokine concentrations were measured by ELISA and analysed using GraphPad Prism. ${ }^{*} p<0.05,{ }^{\dagger} p<0.005,{ }^{\ddagger} p<0.0001$

drivers of innate and acquired immune responses. Following activation, iNKT cells are able to rapidly produce large quantities of IFN- $\gamma$, IL-4 and granulocyte-macrophage colony-stimulating factor, as well as multiple other cyto- kines and chemokines (e.g. IL-2, IL-10 and TNF- $\alpha$ ). In this way, iNKT cells mediate both anti-inflammatory Th2-type, regulatory $\mathrm{T}$ cell-type and pro-inflammatory Th1-type immune responses [14].

Previous studies have demonstrated natural killer cells and NKT cells in psoriasis plaques to be associated with reduced numbers in the circulation $[25,26]$. It is also known that psoriatic keratinocytes are enriched in CD1d, the molecule that presents glycolipid antigen to iNKT cells [27], and that a CD1d reactive $\mathrm{T}$ cell line from a patient with psoriasis induced psoriasis in a mouse model [28]. We have demonstrated a reduction in psoriatic plaque iNKT cell number and an increase in circulatory iNKT cell number, following 6 weeks of GLP-1 analogue therapy. By contrast, a previous study investigated the stability of iNKT cell frequency over time and found that healthy donors displayed constant levels over a period of 10 months [29]. GLP-1 has been shown to inhibit chemokine-induced migration of human CD4-positive lymphocytes in vitro, a critical step in vascular atherosclerotic plaque development [22]. Inhibition of dipeptidyl peptidase-4 enzymatic degradation of GLP-1 prevented recruitment of pro-inflammatory macrophages into visceral fat in a mouse model of type 2 diabetes [30]. These modulatory effects of GLP-1 on immune cell subsets may have important implications for a range of inflammatory and autoimmune conditions.

The established role of GLP-1 is the regulation of postprandial glucose excursions by stimulating insulin secretion, inhibiting glucagon release and causing a delay in gastric emptying. However, a growing body of literature has reported
Fig. 5 The GLP-1 analogue liraglutide modulates iNKT cell cytokine production, but not cytolytic degranulation of iNKT cells. a IFN- $\gamma$ and (b) IL-4 production by iNKT cells $(1 \times$ $10^{5}$ ) co-cultured at a $1: 1$ ratio with CD1d-transfected C1R cells unloaded or loaded with $100 \mathrm{ng} / \mathrm{ml}$ of $\alpha \mathrm{GalCer}$ in the presence of $15 \mu \mathrm{g} / \mathrm{ml}$ of the GLP-1 analogue. Cytokine concentrations were measured by ELISA and analysed using GraphPad Prism $(n=3)$. c Percentage of CD107-positive iNKT cells after culture with CD1d-transfected target cells using the HeLa cell line and (d) Jurkat cell line in the absence or presence of $\alpha$-GalCer and GLP1 analogue treatment. Results are means \pm SEM of experiments using three different iNKT cell lines. ${ }^{\dagger} p<0.0001$
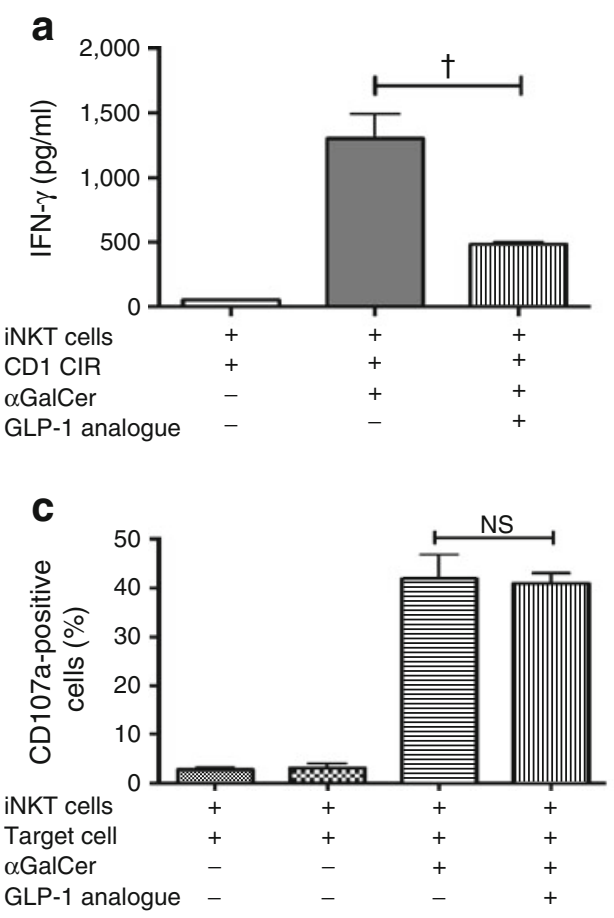
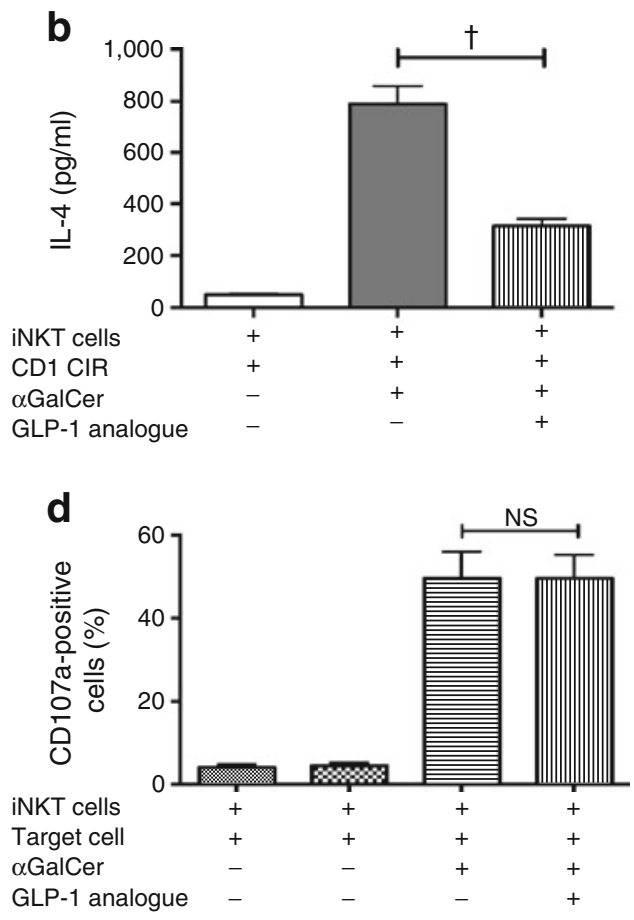
important extra-pancreatic effects of native GLP-1 and GLP-1 receptor agonists. Cardiovascular [31-33], neuroprotective [34-36] and anti-inflammatory [37, 38] effects have been described, along with potential therapeutic implications for multiple disease states. GLP-1 therapy has been shown to delay the onset of diabetes and restore normoglycaemia in mouse models of type 1 diabetes [39, 40]. The beneficial effects of GLP-1 in type 1 diabetes are attributed to trophic and cytoprotective effects on pancreatic beta cells. In addition, there is evidence for an immunoregulatory role, with reports of a shift in cytokine production by islet-infiltrating leucocytes [39] and of modulation of regulatory $\mathrm{T}$ cells [21, 41].

The GLP-1R has been demonstrated in murine immune tissues [20], and on T and B lymphocytes from mice [20, 21] and humans [22]. We have now demonstrated that GLP$1 \mathrm{R}$ is expressed on human iNKT cells. Unlike conventional $\mathrm{T}$ cells, iNKT cells are innate immune cells, capable of powerful anti-tumour cytotoxicity responses and rapid cytokine production following direct antigen stimulation. The balance of pro- and anti-inflammatory cytokines produced influences the inflammatory environment and the subsequent adaptive immune response.

The GLP-1R on iNKT cells is functional and signals in response to GLP-1. This conclusion is based on the ability of GLP-1 to promote increased levels of cAMP and induce phosphorylation of the downstream transcription factor CREB. These are typical responses of receptors like GLP$1 \mathrm{R}$, which signals via the Gs protein to activate adenylate cyclase and increase levels of cAMP. Kim et al. reported that treatment of mice with a dipeptidyl peptidase-IV (DPPIV) inhibitor resulted in an increase in cAMP levels, but the same was not observed with GLP-1 treatment [23]. We have now demonstrated that activation of GLP-1R on iNKT cells results in a significant increase in cAMP levels. The difference in findings may be explained by our use of a DPP-IV-resistant GLP-1 analogue. Native GLP-1 is rapidly degraded by DPP-IV in the circulation and has a half-life of less than 1 to $2 \mathrm{~min}$ [42], whereas liraglutide, a GLP-1 analogue, has a half-life of $13 \mathrm{~h}$ [43]. It is also of interest that GLP-1 promotes activation of the transcription factor CREB. The latter is known to regulate expression of antiinflammatory genes such as $I L 10$ [44], and it is intriguing to speculate that some of the therapeutic effects of liraglutide observed in the present study in psoriatic patients may be related to CREB-induced production of anti-inflammatory proteins. This is worthy of future investigation.

The addition of native GLP-1 or the GLP-1 analogue to the iNKT cell co-cultures in vitro resulted in modulation of biological activity, altering production of the cytokines IFN$\gamma$ and IL-4. GLP-1 modified the cytokine production but not the cytolytic activity of activated iNKT cells. We suggest that GLP-1 is immunoregulatory as opposed to immunosuppressive. The ability of GLP-1 to prime and inhibit iNKT cell cytokine production supports previous work indicating an immune cell regulatory role for this hormone $[20-23,39]$. The GLP-1R antagonist exendin 939 was shown to block the modulation of iNKT cell cytokine production by GLP-1. This confirms that the modulation observed in iNKT cell cytokine production is mediated by GLP-1R activation.

The patients in this report had subjective improvement of psoriasis symptoms within $48 \mathrm{~h}$ of starting GLP-1 analogue therapy, prior to significant weight loss. In addition, the first patient (index patient) displayed improvement with initial GLP1 agonist therapy, deterioration upon withdrawal and rapid improvement following re-treatment with a GLP-1 analogue. In a murine model, Hadjiyanni et al. reported that lymphocytes from $\mathrm{GlpI}^{-/-}$mice were hyperproliferative in response to mitogenic stimulation, suggesting that GLP-1 may control lymphocyte proliferation in mice [21]. Our data suggest that the rapid clinical improvement observed in these psoriasis patients may be secondary to direct regulation of iNKT cells by a GLP-1 analogue. This is supported by alterations in iNKT cell distribution in vivo and cytokine production in vitro.

Liraglutide therapy was commenced in the two nonindex study participants following the observed improvement in psoriasis in the index patient. Glycaemic control was excellent at baseline and remained unchanged. Both non-index participants in the study lost weight after 6 weeks of therapy. Weight loss has previously been shown to positively affect circulating immune cell function in mice [45] and humans [46]. In particular, bariatric surgeryinduced weight loss was shown to reverse impairments in natural killer cell activity and natural killer cell-related cytokine synthesis [47]. It is difficult to determine to what exact extent reduced energy intake or changes in adipose tissue mass may contribute to the noted changes in iNKT cell function. However, all patients reported symptom relief within days of commencing treatment. Expression of the GLP-1R on the iNKT cell and modulation of cytokine production in vitro suggest a specific GLP-1-mediated effect, further supported by the inhibition of these effects by the GLP-1R antagonist exendin (9-39).

Psoriasis has been shown to improve following Rouxen-Y gastric bypass (RYGB) surgery [48]. This is thought to be secondary to substantial weight loss and associated improvements in metabolic and inflammatory markers. RYGB also results in an early and sustained increase in postprandial GLP-1 levels [49]. The in vitro effects of GLP1 analogues on iNKT cells demonstrated in the current study suggest that the improvement in psoriasis following RYGB may be mediated, at least in part, by the effect of GLP-1 on iNKT cell cytokine production.

This study focused exclusively on human iNKT cells and indicates that GLP-1 and GLP-1-based therapies directly influence human immune function. While the effects seen 
in this report are positive in psoriasis, extensive research is needed to investigate the potential beneficial or adverse effects of direct GLP-1-immune cell interactions. The observation that GLP-1 therapy restores circulating iNKT cell number, directly primes a resting iNKT cell and inhibits a stimulated iNKT cell further strengthens the link between the endocrine and human immune system, indicating potential new therapeutic applications for GLP-1 therapies.

Acknowledgements The authors would like to thank the UCD Newman Fellowship program for funding A.E. Hogan.

Contribution statement A.E.H., A.M.T., T.A., M.A.C., G.G., V. O'R. and R.J. contributed to the experimental design, data collection, analysis and manuscript preparation. A.E.H., J.O'C., P.N.M., D.G.D., L.L., B.K. and D.O'S. contributed to the experimental design, manuscript preparation, data analysis and intellectual input. All authors have approved the final version of the paper.

Duality of interest The authors declare that there is no duality of interest associated with this manuscript.

Open Access This article is distributed under the terms of the Creative Commons Attribution Noncommercial License which permits any noncommercial use, distribution, and reproduction in any medium, provided the original author(s) and source are credited.

\section{References}

1. Neimann AL, Shin DB, Wang X, Margolis DJ, Troxel AB, Gelfand JM (2006) Prevalence of cardiovascular risk factors in patients with psoriasis. J Am Acad Dermatol 55:829-835

2. Gisondi P, Tessari G, Conti A et al (2007) Prevalence of metabolic syndrome in patients with psoriasis: a hospital-based case-control study. Br J Dermatol 157:68-73

3. Sommer DM, Jenisch S, Suchan M, Christophers E, Weichenthal M (2006) Increased prevalence of the metabolic syndrome in patients with moderate to severe psoriasis. Arch Dermatol Res 298:321-328

4. Qureshi AA, Choi HK, Setty AR, Curhan GC (2009) Psoriasis and the risk of diabetes and hypertension: a prospective study of US female nurses. Arch Dermatol 145:379-382

5. Wellen KE, Hotamisligil GS (2005) Inflammation, stress, and diabetes. J Clin Invest 115:1111-1119

6. Spah F (2008) Inflammation in atherosclerosis and psoriasis: common pathogenic mechanisms and the potential for an integrated treatment approach. Br J Dermatol 159(Suppl 2):10 17

7. Mallbris L, Akre O, Granath $\mathrm{F}$ et al (2004) Increased risk for cardiovascular mortality in psoriasis inpatients but not in outpatients. Eur J Epidemiol 19:225-230

8. Gelfand JM, Neimann AL, Shin DB, Wang X, Margolis DJ, Troxel AB (2006) Risk of myocardial infarction in patients with psoriasis. JAMA 296:1735-1741

9. Wilson PW, D'Agostino RB, Sullivan L, Parise H, Kannel WB (2002) Overweight and obesity as determinants of cardiovascular risk: the Framingham experience. Arch Intern Med 162:18671872

10. Lynch LA, O'Connell JM, Kwasnik AK, Cawood TJ, O'Farrelly C, O'Shea DB (2009) Are natural killer cells protecting the metabolically healthy obese patient? Obesity (Silver Spring) 17:601-605
11. Lynch L, O'Shea D, Winter DC, Geoghegan J, Doherty DG, O'Farrelly C (2009) Invariant NKT cells and CD1d(+) cells amass in human omentum and are depleted in patients with cancer and obesity. Eur J Immunol 39:1893-1901

12. Liu TY, Uemura Y, Suzuki M et al (2008) Distinct subsets of human invariant NKT cells differentially regulate $\mathrm{T}$ helper responses via dendritic cells. Eur J Immunol 38:1012-1023

13. Peternel S, Kastelan M (2009) Immunopathogenesis of psoriasis: focus on natural killer T cells. J Eur Acad Dermatol Venereol 23:1123-1127

14. Taniguchi M, Tashiro T, Dashtsoodol N, Hongo N, Watarai H (2010) The specialized iNKT cell system recognizes glycolipid antigens and bridges the innate and acquired immune systems with potential applications for cancer therapy. Int Immunol 22:1-6

15. Molling JW, Langius JA, Langendijk JA et al (2007) Low levels of circulating invariant natural killer $\mathrm{T}$ cells predict poor clinical outcome in patients with head and neck squamous cell carcinoma. J Clin Oncol 25:862-868

16. Tudhope SJ, von Delwig A, Falconer J et al (2010) Profound invariant natural killer T-cell deficiency in inflammatory arthritis. Ann Rheum Dis 69:1873-1879

17. Kaieda S, Tomi C, Oki S, Yamamura T, Miyake S (2007) Activation of invariant natural killer $\mathrm{T}$ cells by synthetic glycolipid ligands suppresses autoantibody-induced arthritis. Arthritis Rheum 56:1836-1845

18. Girard J (2008) The incretins: from the concept to their use in the treatment of type 2 diabetes. Part A: Incretins: concept and physiological functions. Diabetes Metab 34:550-559

19. Holst JJ (2007) The physiology of glucagon-like peptide 1 . Physiol Rev 87:1409-1439

20. Hadjiyanni I, Baggio LL, Poussier P, Drucker DJ (2008) Exendin4 modulates diabetes onset in nonobese diabetic mice. Endocrinology 149:1338-1349

21. Hadjiyanni I, Siminovitch KA, Danska JS, Drucker DJ (2010) Glucagon-like peptide-1 receptor signalling selectively regulates murine lymphocyte proliferation and maintenance of peripheral regulatory T cells. Diabetologia 53:730-740

22. Marx N, Burgmaier M, Heinz P et al (2010) Glucagon-like peptide-1(1-37) inhibits chemokine-induced migration of human CD4-positive lymphocytes. Cell Mol Life Sci 67:3549-3555

23. Kim SJ, Nian C, Doudet DJ, McIntosh CH (2009) Dipeptidyl peptidase IV inhibition with MK0431 improves islet graft survival in diabetic NOD mice partially via T-cell modulation. Diabetes 58:641-651

24. Matsuda JL, Mallevaey T, Scott-Browne J, Gapin L (2008) CD1drestricted iNKT cells, the 'Swiss-Army knife' of the immune system. Curr Opin Immunol 20:358-368

25. Cameron AL, Kirby B, Fei W, Griffiths CE (2002) Natural killer and natural killer-T cells in psoriasis. Arch Dermatol Res 294:363-369

26. Cameron AL, Kirby B, Griffiths CE (2003) Circulating natural killer cells in psoriasis. Br J Dermatol 149:160-164

27. Bonish B, Jullien D, Dutronc Y et al (2000) Overexpression of CD1d by keratinocytes in psoriasis and CD1d-dependent IFNgamma production by NK-T cells. J Immunol 165:4076-4085

28. Nickoloff BJ, Bonish B, Huang BB, Porcelli SA (2000) Characterization of a $\mathrm{T}$ cell line bearing natural killer receptors and capable of creating psoriasis in a SCID mouse model system. J Dermatol Sci 24:212-225

29. Lee PT, Putnam A, Benlagha K, Teyton L, Gottlieb PA, Bendelac A (2002) Testing the NKT cell hypothesis of human IDDM pathogenesis. J Clin Invest 110:793-800

30. Shirakawa J, Fujii H, Ohnuma K et al (2011) Diet-induced adipose tissue inflammation and liver steatosis are prevented by DPP-4 inhibition in diabetic mice. Diabetes 60:1246-1257

31. Chilton R, Wyatt J, Nandish S, Oliveros R, Lujan M (2011) Cardiovascular comorbidities of type 2 diabetes mellitus: defining 
the potential of glucagonlike peptide-1-based therapies. Am J Med 124:S35-S53

32. Nikolaidis LA, Mankad S, Sokos GG et al (2004) Effects of glucagon-like peptide-1 in patients with acute myocardial infarction and left ventricular dysfunction after successful reperfusion. Circulation 109:962-965

33. Ban K, Noyan-Ashraf MH, Hoefer J, Bolz SS, Drucker DJ, Husain M (2008) Cardioprotective and vasodilatory actions of glucagon-like peptide 1 receptor are mediated through both glucagon-like peptide 1 receptor-dependent and -independent pathways. Circulation 117:2340-2350

34. Holst JJ, Burcelin R, Nathanson E (2011) Neuroprotective properties of GLP-1: theoretical and practical applications. Curr Med Res Opin 27:547-558

35. Lerche S, Brock B, Rungby J et al (2008) Glucagon-like peptide-1 inhibits blood-brain glucose transfer in humans. Diabetes 57:325-331

36. Mcclean PL, Gault VA, Harriott P, Hölscher C (2009) Glucagonlike peptide-1 analogues enhance synaptic plasticity in the brain: a link between diabetes and Alzheimer's disease. Eur J Pharmacol 630:158-162

37. Kodera R, Shikata K, Kataoka HU et al (2011) Glucagon-like peptide-1 receptor agonist ameliorates renal injury through its anti-inflammatory action without lowering blood glucose level in a rat model of type 1 diabetes. Diabetologia 54:965-978

38. Hattori Y, Jojima T, Tomizawa A et al (2010) A glucagon-like peptide-1 (GLP-1) analogue, liraglutide, upregulates nitric oxide production and exerts anti-inflammatory action in endothelial cells. Diabetologia 53:2256-2263

39. Suarez-Pinzon WL, Power RF, Yan Y, Wasserfall C, Atkinson M, Rabinovitch A (2008) Combination therapy with glucagon-like peptide-1 and gastrin restores normoglycemia in diabetic NOD mice. Diabetes 57:3281-3288
40. Zhang J, Tokui Y, Yamagata K et al (2007) Continuous stimulation of human glucagon-like peptide-1 (7-36) amide in a mouse model (NOD) delays onset of autoimmune type 1 diabetes. Diabetologia 50:1900-1909

41. Xue S, Wasserfall CH, Parker M et al (2008) Exendin-4 therapy in NOD mice with new-onset diabetes increases regulatory $\mathrm{T}$ cell frequency. Ann N Y Acad Sci 1150:152-156

42. Deacon CF, Nauck MA, Toft-Nielsen M, Pridal L, Willms B, Holst JJ (1995) Both subcutaneously and intravenously administered glucagon-like peptide I are rapidly degraded from the NH2-terminus in type II diabetic patients and in healthy subjects. Diabetes 44:1126-1131

43. Deacon CF (2004) Therapeutic strategies based on glucagon-like peptide 1. Diabetes 53:2181-2189

44. Mellett M, Atzei P, Jackson R, O’Neill LA, Moynagh PN (2011) Mal mediates TLR-induced activation of CREB and expression of IL-10. J Immunol 186:4925-4935

45. Lamas O, Martinez JA, Marti A (2004) Energy restriction restores the impaired immune response in overweight (cafeteria) rats. J Nutr Biochem 15:418-425

46. Tanaka S, Inoue S, Isoda F et al (1993) Impaired immunity in obesity: suppressed but reversible lymphocyte responsiveness. Int J Obes Relat Metab Disord 17:631-636

47. Moulin CM, Marguti I, Peron JPS, Halpern A, Rizzo LV (2011) Bariatric surgery reverses natural killer (NK) cell activity and NKrelated cytokine synthesis impairment induced by morbid obesity. Obes Surg 21:112-118

48. Hossler EW, Maroon MS, Mowad CM (2011) Gastric bypass surgery improves psoriasis. J Am Acad Dermatol 65:198-200

49. Mingrone $G$ (2008) Role of the incretin system in the remission of type 2 diabetes following bariatric surgery. Nutr Metab Cardiovasc Dis 18:574-579 